Scientific Journal Warsaw University of Life Sciences - SGGW

Problems of World Agriculture volume 18 (XXXIII), number 2, 2018: 175-182

DOI: 10.22630/PRS.2018.18.2.45

Julian T. Krzyżanowski ${ }^{1}$

Warsaw University of Life Sciences - SGGW

\title{
The Evaluation of Implementation of Agricultural Sustainable Development Policy in the European Union
}

\begin{abstract}
Author tries to evaluate two elements of implementation of agricultural sustainable development policy in the European Union. Those elements are: "greening" and European innovation partnership. Greening is carried out by: crop diversification, maintenance of permanent grassland (PG), maintenance of ecological focus areas (EFA). Diversification of crops was carried out for three fourth of areas of arable lands in the EU. Diversification prevents soil erosion. Share of PG in the overall area of agricultural land in the EU is $29 \%$. The highest indicator is at present in the United Kingdom (90\%), and the lowest in Cyprus, Malta, Denmark and Finland. From the set of actions maintaining the pro-environmental areas (EFA), the most popular were: setting aside (27 member states), and the least popular - afforestation (only 11 countries). When it comes to EFA area, the biggest share was the area for legume plants. New pro-environmental instrument is European Innovation Partnership for productive and sustainable agriculture. There has already been some results of this action in the EU countries.
\end{abstract}

Key words: agriculture, European Union, „,greening”, EIP

JEL Classification: O13, Q01, Q18

\section{Introduction}

The goal of this paper is to determine development in implementation of two elements of sustainable agriculture policy ("greening" and European innovation partnership) in the countries of the European Union. Plans and programs for 2014-2020 were developed i.a. in the EU documents (i.a. working document of the Commission (Impact, 2011), with a characteristic title "Greening of the CAP").

Sustainable development of agriculture is implemented through numerous instruments. There are also many classifications of those tools used in environmental economics and environment-protection policy.

In previous work (Krzyżanowski, 2016), a following division of instruments was proposed: legal acts, direct support instruments (subventions), which will be subject to detailed analysis, economic (taxes and fees) commercial measures, scientific research and environmental education. Discussion of the last instrument was omitted previously, but it will be brought up again due to large interest in this tool in new form and due to the significance which the European Commission attaches to its implementation.

\footnotetext{
${ }^{1} \mathrm{PhD}$, associated professor, Department of Agricultural Economics and International Economic Relations WULS-SGGW, ul. Nowoursynowska 166,02-787 Warszawa, e-mail: julian_krzyzanowski@sggw.pl; https://orcid.org/0000-0001-6418-154X
} 


\section{Implementation of policy of sustainable development of EU agriculture}

The communication from the European Commission (Communication, 2010) determining directions of CAP development until 2020, indicates one of main tasks for following years, namely ensuring environmental sustainability. This term has, in turn, a essential meaning for the category of sustainable development (Jeżowski, 2015).

Environmental sustainability is implemented through following instruments: new proenvironmental payment in the frame of pillar I, extension of principles of cross- compliance by climate changes (Webster, 2002), two priorities concerning environmental protection in Rural Development Program (RDP) and European innovation partnership for productive and sustainable agriculture. Thus, the two main components of financial support of the Common Agricultural Policy, direct payments and RDP include instruments affecting the sustainable development of agriculture and rural areas.

Payment due to agricultural practices favorable to climate and environment, i.e. "greening" is a mandatory component of new system of direct payments. "Greening" is a CAP instrument introduced for the 2014-2020 financial perspective. Its financing will be covered by $30 \%$ of national financial envelope, so in Poland it will be 1 billion EUR a year (for more details - see (Krzyżanowski, 2015)).

Greening is carried out by:

- Crop diversification

- $\quad$ Maintaining permanent grassland (PG)

- Maintenance of ecological focus areas (EFA) ${ }^{2}$.

Moreover, it is possible to perform the diversification of crops through equivalence measures in the frame of agri-environment-climate measure RDP 2014-2020.

Maintaining pro-environmental areas applies to farms of over 15 ha of arable lands, which are obliged to have pro-environmental EFA areas on at least on the area of $5 \%{ }^{3}$ of arable land

Farmers may include the following elements to pro-environmental areas:

1) Fallow lands - on which, from January 1 until July 31, in a given year there is no agricultural production (after expiration of this term, the farmer will be allowed to perform production on this area),

2) Landscape features, which are owned by the farmer (located on fallow land, or directly adjacent to them),

3) Buffer areas, including buffer areas on permanent grassland,

4) Land qualified for payment along the forest edges - of width from $1 \mathrm{~m}$ to $10 \mathrm{~m}$,

5) Short rotation coppices with low rotation, on which it is forbidden to use plant protection products and it is possible to use mineral fertilization within certain limits,

6) Areas afforested after 2008, in the frame of RDP 2007-2013 (afforestation of rural land) and RDP 2014-2020, which were eligible for single area payment in 2008.

7) Catch crops or green cover - in the form of catch crops of main crops to mixtures created of at least 2 types.

\footnotetext{
${ }^{2}$ EFA - ang. ecological focus area.

${ }^{3}$ This percentage, after presenting by the European Commission of the report assessing the implementation of this practice after 2017, could be increased to $7 \%$, but it has not been done [europarl. 2017].
} 
8) Area of nitrogen-fixing (area of EFA shall be $70 \%$ of the nominal area).

In the case of large diversity of ecological focus areas between neighboring farms, they can use a possibility of the common implementation of this requirement. (Krzyżanowski, 2015).

When initiating new payments, the Commission declared to evaluate the implementation of EFA instrument after first year of its existence, namely in 2016 (ec.europa, 2014). Before that, member states, by Regulation 1307/2013 were obliged i.e. to select, until August 2014, particular greening elements: equivalence measures, maintenance of a certain share of PG in the area of arable land, list of EFA areas, application of conversion and weighing coefficients and possibility of common implementation of EFA practice (Krzyżanowski, 2015).

As far as equivalence measures are concerned, only five countries: Austria, France, Holland, Ireland and Poland accepted it. The possibility of common implementation of EFA practices was declared by only two countries: Holland and Poland.

Among elements of pro-environmental areas, all countries (except for Holland and Romania), selected the fallow lands, landscape elements -24 countries, short rotation coppices 20 countries, buffer zones - 17 countries, afforested areas - 11 countries (ec.europa, 2017). Other source (Commission, 2016) indicates that farmers decided to seed nitrogen-fixing plants (legumes) on $45,9 \%$ of the total area of EFA.

Thus, experience of the first year concerning maintenance of pro-environmental EFA areas are positive, especially when it comes to introduction of legume plants and fallow lands.

On the basis of reports of particular countries, The European Commission developed in 2015 (Commission, 2016) a state of implementation of "green payments". The area of agricultural lands in the EU covered at least by one requirement for receiving a payment, is $72 \%$ of the entire area (fig. 1). This shows the scale of environmental-climate benefits. The above-mentioned criterion is met by $36 \%$ of farmers.

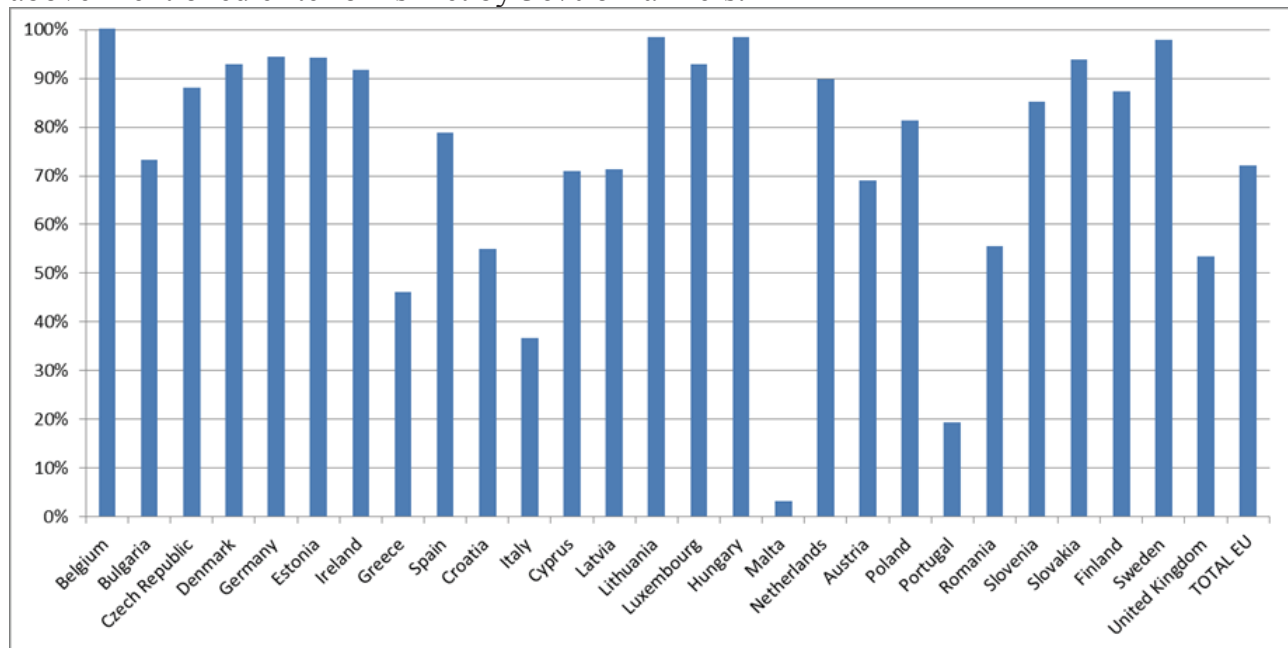

Fig. 1. Relation of areas of farms covered by at least one "greening" requirement to the overall crop area.

Source: (Commission, 2016). 
Crop diversification concerns farms of at least 10 ha of arable land, whereas the farms:

a) of 10 - 30 ha of arable areas - shall have at least 2 different crops on arable lands, whereas the main crop cannot take more than $\mathbf{7 5 \%}$ of arable lands.

b) Above $\mathbf{3 0}$ ha of arable lands - shall have at least $\mathbf{3}$ different crops on arable lands, whereas the main crop shall not take more than $\mathbf{7 5 \%}$ of arable lands.

Arable lands subject to requirement of diversification of crops are $75 \%$ of EU overall area of these lands. However, the differences are great, from a few percent on Malta to almost $100 \%$ in Hungary (in Poland - almost 70\%). Such different rates reflect differentiated structure of farms, in accordance with assumed principles that the bigger farm, the bigger diversification and respective are of it (fig. 2).

The detailed data analysis (Commission, 2016) shows that on $8 \%$ of arable land, being $10 \%$ of area subject to diversification, farmers had to introduce new plants. This is in turn $1 \%$ of the cultivated land. Thus, on one hand, difficulties are not too harmful, but on the other hand, they allow to fight erosion of the soil, which attacks around $13 \%$ of arable lands in EU countries.

Another method to maintain the biological diversity, understood as richness of elements on particular levels of organization of nature is to keep permanent grassland (PG). In member states, there is an obligation to maintain the participation of PG in agricultural areas on the country scale, whereas it cannot be decreased by more than $5 \%$ in relation to the reference level in 2015.

Share of PG in the overall area of agricultural land in the EU is $29 \%$. The highest indicator is at present in the United Kingdom (90\%), and the lowest in Cyprus, Malta, Denmark and Finland.

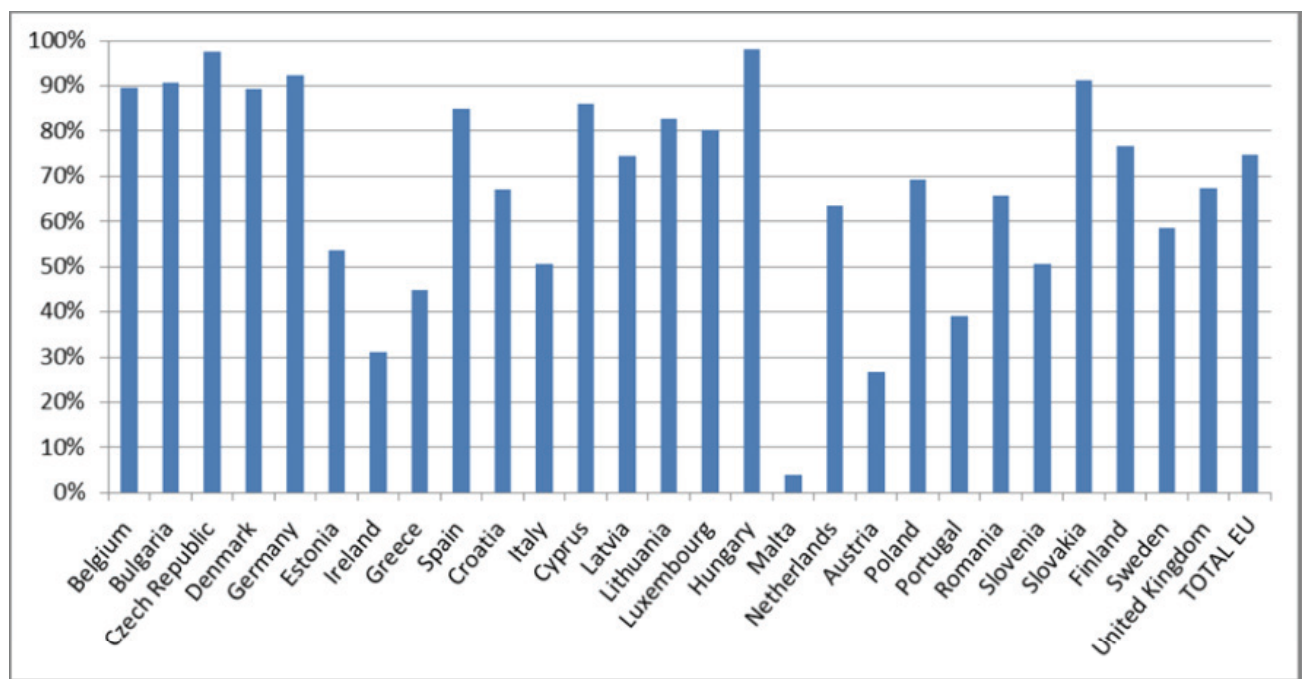

Fig. 2. Share of arable land subject to requirements of crop diversification in relations to the overall area of these lands.

Source: (Commission, 2016). 
PG that are environmentally-valuable (Krzyżanowski, 2015) make $16 \%$ of the overall permanent grassland areas, and according to declarations of farmers, $40 \%$ of PG belong to the Natura 2000 areas.

It should be mentioned, that low percentage of agricultural areas in EU is excluded from "greening" obligation. This applies i.a. to farms participating in program for small farms, which are $41 \%$ of all farms, but at the same time they occupy only $5 \%$ of overall agricultural areas covered by direct payments.

Equivalence measures, applied by agricultural-environmental-climate RDP instead of classical crop diversification, are introduced in six member states for $6 \%$ of overall area of arable land and are operated by only $2 \%$ of farmers. However, in e.g. Austria, equivalence measures are practiced by $19 \%$ of farmers on over half of arable lands in that country.

All in all, it might be stated that "green" payments are applied for a significant area of agricultural areas. However, real environmental results depend on particular choices made by farmers from available means and procedures. For instance, when it comes to maintaining the EFA environmental areas, farmers, for most part, selected elements of the program connected with crops (production) much more often than landscape elements, although the latter create a larger bio-diversity effect than the former.

According to the Commission communication, crop diversification, applied on most of arable land prevents deterioration of soil. Efficiency of maintaining permanentble grassland depends in turn on respecting principles of non-transforming PG into arable lands.

When introducing "greening", there were concerns that farmers will have to change the allocation of land which might affect the production capabilities. This was supposed to be the case for both set-aside lands and due to introduction of EFA - decreased intensity of application of crop-creating agents.

Analyses show however that introduction of ,green" payments does not affect the amount of agricultural production. Obligation to diversify crops (as one of greening elements) neither affected allocation of land for different purposes, nor the overall production capacity.

Instrument of diversification efficiently "spots" these farms that only have one crop. Research (Commission, 2016) show that relocation concerns above all, wheat, barley and maize.

Analyses show that a certain effect of introduction of "green" payments is low growth of PG areas, set-aside (fallow) lands and protein-rich plants in the overall area, in relation to situations before introducing "greening". After introducing current reform, agricultural production has changed by $1,5 \%$. Only production of protein-rich plants has increased by over 5\%. Whereas, when it comes to PG areas, it is estimated that due to use of "green" payments, it will grow by $3,2 \%$ until 2025 .

When it comes to maintaining pro-environmental areas, in long-term, the set-aside area will increase by $8,9 \%$, protein-rich plants by $4,4 \%$. Thus, it is estimated that current trend of decrease of set-aside areas will be changed.

As it was already mentioned, results of "greening" depend in many cases on choices made by member states and farmers. This concerns above all, introducing EFA element, when only few countries decreased use of plant-protection agents and fertilizers on proenvironmental areas. Landscape elements, important for protection of biodiversity, were not priority in EFA for many countries. Application of crop diversification for most of the area was already mentioned. Thus, at least the process of degradation of land will be stopped. 
Control of proper PG share in overall area of agricultural lands contributes to carbon sequestration.

Next evaluation of "greening" is to be prepared for 2017-2018 (ec.europa, 2017).

\section{European Innovation Partnership for innovation for Agricultural Productivity and Sustainability - new instrument of European Commission.}

European innovative partnership for efficient and sustainable agriculture (EIP-AGRI) was found in 2012 as an instrument, which in financial perspective 2014-2020 is to contribute to increase of environmental sustainability. It is to contribute to implementation of European Union - Europa 2020 strategy for smart, sustainable and inclusive economic growth. Strengthening of research and innovation is one of five main goals of this strategy, which promotes new interactive approach to support innovation, namely European partnership for innovation (ec.europa.eu/agriculture/research, 2017). It may be said that this is a tool for environmental education.

European partnership for innovation in agriculture in Poland (EIP-AGRI) acts for the benefit of competitive and sustainable agriculture and forestry, so that these sectors can develop with smaller use of resources. EIP-AGRI contributes to ensuring stables supplies of food, feed and biomaterials, protecting the basic natural resources, on which agriculture and forestry are based.

Innovative projects in agriculture may be financed from various sources, such as European rural development policy of the EU or a program concerning scientific research and innovations - Horizon 2020. Within EIP-AGRI, farmers, advisors, scientists, agri-businessmen, NGOs and other entities cooperate as innovation partners in agriculture and forestry. Together, they create the union-wide network managed by European Commission.

It is practically a new measure by RDP (priority 11 . Fostering innovation, cooperation and the development of the knowledge base in the rural areas), aiming at creating operational groups for innovations - EIP which have to lead to development of new solutions.

For this action there is 37 million EURO in Poland, and along with national resources - almost 58 million EURO. Support deals with creating and everyday work of operating groups for innovation (EIP) and projects that are implemented by those groups, which lead to development of solution in areas of new products, practices, processes, technologies, methods of organization and marketing in the following sectors: agricultural, food industry and forestry.

The level of support covers 100 percent of expenses qualified in case of general costs connected with current costs of activities of operating group, feasibility studies, preparation of operation plan of the group, animation, promotion of operation results, preparation of business plan.

In case of research, directly connected with implementation of the operation objective, the level of support is 90 percent of amount of qualified expenses. Overall maximum value of support connected with direct expenses of the operation and costs of research of the EIP operating group is 10000000 PLN. 
For better information flow, an institution was assigned as the innovation broker. In Poland, such broker is Agricultural Advisory (Extension) Center (CDR) in Brwinów.

Let us present results of work on the EU level of two operation groups. First one is "water in agriculture: adaptation strategies on the farm level". Activities by 19 experts were carried out in 2015/2016. Strategies were developed with reference to research done by one of the members.

In the final report, the group stated that availability of water for farms may be increased by introducing strategies that limit losses or increase possibilities to store water. It was also stated that the best way to save water is soil mulching. Among other actions, the following were mentioned: selection of plants characterized by high efficiency of water use (eip-agri-water, 2017) or precise watering.

Second group worked on „efficiency of fertilizing - gardening”. Group of 20 experts studied the following issue: "How to use modern fertilization and recycling of nutrients to solve the conflict between a necessity to fertilize and legal requirements concerning water quality?" (www.ifoam, 2017).

\section{Summary}

Sustainable development of agriculture and rural areas is implemented, above all, by instruments of pillar I and CAP, including "green" payments. Member states had the opportunity to select particular elements of "greening". Only 5 countries decided to use equivalence measures. Only two EU members chose the possibility of common implementation of EFA practice.

From the set of actions maintaining the pro-environmental areas, the most popular were: setting aside (27 member states), and the least popular - afforestation (only 11 countries). When it comes to EFA area, the biggest share was the area for legume plants.

When it comes to implementation of "green payments" in 2015 , on one hand, $72 \%$ of areas of agricultural areas in EU member states were included in at least one requirement of "greening" on the other hand - this applied to only $36 \%$ of all farmers.

Diversification of crops was carried out for three fourth of areas of arable lands. According to research by European Commission (Commission, 2016), the introduced hindrances are not too harmful. On the other hand, diversification prevents soil erosion. It should be noted (Krzyżanowski, 2015) that diversification concerns farms of 10 ha area of arable lands. Farms of 10-30 ha of arable lands - are obliged to have at least 2 different crops on arable lands whereas the main crop cannot exceed $75 \%$ of the arable land.

New pro-environmental instrument is European Innovation Partnership for productive and sustainable agriculture. There has already been some results of this action in the EU, Poland included. EIP projects integrate entire agricultural environment (manufacturers, advisors, scientists, NGOs, etc.). In our country, EIP operation groups contribute to development and reinforcement of organic agriculture.

\section{References}

Commission staff working paper, Impact Assessment,(2011) Common Agricultural Policy towards 2020, Brussels. Commission staff working document, review of greening after one year, Brussels, (2016) 218 final, Part 1/6. 
Communication from the Commission to the European Parliament, the Council, the Economic and Social Committee and the Committee of the Regions (2010), The CAP Towards 2000: Meeting the Food, Natural Resources and Territorial Challenges of the Future, European Commission, COM 672.

https://ec.europa.eu/eip/agriculture/en/content/eip-agri-focus-group-water-and-agriculture-final-report.

https://ec.europa.eu/agriculture/research-innovation_en.

https://ec.europa.eu/agriculture/sites/agriculture/files/direct-support/direct-payments/docs/implementationdecisions-ms_en.pdf 2017.

https://enrd.ec.europa.eu/policy-in-action/rural-development-policy-figures/priority-focus-area-summaries en.

http://www.europarl.europa.eu/cmsdata/117863/COMAGRI-02-05-2017_D\%20slides_\Ecological\%20Focus\%20 Areas.pdf.

http://www.ifoam eu.org/sites/default/files/page/files/tpo_eip_dossier_pl_201404.pdf.

Jeżowski, P. (2012). Rozwój zrównoważony i jego nowe wyzwania (The New Challenges of Sustained Development). Kwartalnik Kolegium Ekonomiczno-Spotecznego Studia i Prace 2, 99-124.

Krzyżanowski, J.T. (2016). Instrumenty zrównoważonego rozwoju rolnictwa i obszarów wiejskich (Instruments for the sustainable development of agriculture and rural areas). In: $Z$ badan nad rolnictwem społecznie zrównoważonym (35), (ed.) J.St. Zegar, 24 Monografie Programu Wieloletniego, IERiGŻ- PIB, Warszawa.

Krzyżanowski, J.T. (2015). Wpływ WPR 2014-2020 na zrównoważenie polskiego rolnictwa (The impact of the CAP 2014-2020 on the sustainability of Polish agriculture). In: Z badań nad rolnictwem społecznie zrównoważonym (31), (ed.) J.St. Zegara, 6 Monografie Programu Wieloletniego, IERiGŻ- PIB, Warszawa.

Webster, P., Williams, N. (2002). Environmental cross-compliance, Panacea or Placebo, Imperial Wye College, UK.

\section{For citation:}

Krzyżanowski J.T. (2018). The Evaluation of Implementation of Agricultural Sustainable Development Policy in the European Union. Problems of World Agriculture, 18(2), 175-182; DOI: 10.22630/PRS.2018.18.2.45 